\title{
현장시험을 통한 시멘트 진동주입공법의 보강효과 Improvement Effects of Cement Grouting using Vibration Method through a Field Test
}

\author{
한 상 현 ${ }^{1)}$ 여 규 권 ${ }^{2} \cdot$ 김 홍 연 \\ Sanghyun Han $\cdot$ Geugweun Yea $\cdot$ Hongyeon Kim
}

Received: January $7^{\text {th }}, 2014$; Revised: January 21 $1^{\text {st }}, 2014$; Accepted: March $18^{\text {th }}, 2014$

\begin{abstract}
So far, the grouting using pressure injection has been extensively used to avoid adverse effects such as soil disturbance. Whereas, the pressure injection to the limitations of the diffusion range, so that the kinks would last injection of cement particles by introducing a frequency oscillation effect improved injection method have been recently developed. In this study, a pilot test was performed to compare injection effects of the both methods. The injections using both methods were tested on the embankment which consists of core clay and weathered soil. Subsequently, the injected volume, SPT N values, in-situ permeability and electrical resistivity were measured to compare their effects. The vibration method showed more effective permeation comparing with the pressure method. Also, it showed more homogeneously improved ground than the existing method. For SPT results, the vibration method presented increase of mean $\mathrm{N}$ value as much as $17.4 \%$ comparing with the conventional method. Higher electrical resistivity was presented in case of injecting with vibration method and it indicated the injection was extensively completed. Finally, it is expected that the economic feasibility will be improved by decrease of drilling spacing, when the existing method is replaced with vibration method.
\end{abstract}

Keywords : Vibrated injection, Pressured injection, Grouting, Pilot test, Permeability

요 지: 압력주입에 의한 그라우팅은 지반교란 및 인접지반에 미치는 영향이 적어 현재까지 광범위하게 활용되어 왔다. 반면 저압 주입의 한계로 확산범위가 제한적이므로 그 단점을 보완하고자 최근 시멘트 입자에 주파수를 도입하여 주입효과를 개선한 진동주 입공법이 개발되었다. 본 연구에서는 진동주입 방식에 의한 시멘트 그라우팅 공법의 주입효과를 기존의 압력주입방식과 비교하기 위하여 현장시험을 실시하였다. 점토코어 및 풍화토 지반으로 구성된 제방에서 진동주입 및 기존의 압력주입 방식으로 주입하고 그 효과를 비교하기 위하여 주입량, 표준관입시험, 현장투수시험과 전기비저항탐사를 실시하였다. 주입량을 비교한 결과 가진주입 시 일반주입 대비 약 $15 \%$ 주입량이 증가하여 확산 효과가 큰 것으로 분석되었다. 가진주입한 지반의 투수계수는 일반주입 대비 평균 $50 \%$ 까지 감소하여 균질한 주입이 이루어짐이 확인되었다. 표준관입시험 결과 일반주입과 비교하여 가진주입 시 평균 17.4 $\%$ 가량 $\mathrm{N}$ 치가 증가하였고, 특히 풍화토층에서 개선효과는 일반주입 대비 $19 \%$ 로 주입효과가 큰 것으로 나타났다. 전기비저항탐사 를 이용하여 전체적인 주입효과를 판단한 결과 진동주입 구간의 경우 상대적으로 높은 비저항을 나타내어 균일하고 광범위하게 주입이 이루어진 것으로 나타났다. 이상의 주입효과 비교를 통하여 동일한 지반에서 압력주입을 진동주입으로 대체할 경우 주입공 당 주입재의 양은 증가하지만, 주입재의 확산반경이 커짐에 따라 주입공의 천공간격이 감소함으로써 경제성 개선이 가능할 것으로 판단되었다.

주요어 : 진동주입, 압력주입, 그라우팅, 현장시험, 투수계수

\section{1. 서 론}

지반주입공법은 19 세기 초반에 최초 도입된 이후 각종 토목 및 건축현장에서 지반보강 및 차수보조 등의 목적으로 현재까지도 폭넓게 활용되고 있다. 뿐만 아니라 초기에 단 순한 재료와 주입방식으로부터 많은 개선을 통하여 새로운 개념의 주입재료, 방법 및 장비개발에 이르기까지 지속적으
로 기술의 발전이 거듭되고 있다. 롯드(rod) 그라우팅으로부 터 LW(Labiles Wasser glass), SGR(Space Grouting Rocket system) 공법 등은 이미 상당한 역사가 되었고, JSP(Jumbo Special Pattern), 제트(jet) 그라우팅 등 고압분사공법이 발달 하여 RJP(Rodin Jet Pile), DCM(Deep Cement Mixing) 등의 심층혼합처리공법이 널리 사용되고 있으며, 압밀(compaction) 그라우팅 분야에도 새로운 재료와 시공법이 많이 개발되고

\footnotetext{
1) Department of Civil Engineering, Seoil University

2) Technology Research Division, Sambu Construction Co.

† Technology Research Division, Sambu Construction Co. (Corresponding Author : hykim74@sambu.co.kr)
} 
있다.

일반적으로 그라우팅에는 주재료인 시멘트 계열의 약재 와 이를 적절한 시간에 고형화시키는 고결제가 사용된다. 시멘트 계열의 약재에는 각 공법 및 재료에 따라 화학적 성 분에 차이가 있고, 고결제에는 규산이 함유된 물유리 계열 과 특수한 그라우팅에 사용되는 화학 재료가 있으며 역시 각 공법 및 재료에 따라 화학적 성분에 차이가 있다(Bang et al., 2006). 그러나 재료구득 용이성과 경제성뿐 아니라 현재까지 그 효과가 충분히 검증된 이유로 시멘트 계열의 약재가 가장 널리 쓰이고 있다.

지중에서 약액의 주입방식은 과거에는 기본적으로 저압 의 압력주입 방식이 많이 사용되었으나, 장비기술이 발달하 면서 최근에는 압축공기와 고압수를 이용하여 지반을 절삭 하고 절삭된 원지반 재료와 약재를 혼합하여 대구경, 고강 도의 고결체를 형성할 수 있는 고압분사 방식도 많이 이용 되고 있다. 또한 저유동성 재료를 지중에서 주입하며 밀어 내는 압밀원리로 원지반의 밀도를 높이는 압밀 방식도 널리 보급되는 등 주입방식도 상당히 다양화되어가는 추세이다.

그럼에도 불구하고 Fig. 1에 나타났듯이 시멘트 그라우팅은 시멘트 입자크기와 휽의 공극 관계, 주입 도중 막힘(clogging) 에 따라 적용지반에 다소 제한이 있다. 특히 화학재를 첨가 하여도 실트와 점토 등 세립토 지반과 암반 절리면에서 압 력방식으로 시멘트 약액을 주입하는 것은 쉽지 않으며 그 확산효과도 양호하지 못하다. 이러한 압력주입 방식의 한계 를 극복하기 위하여 최근에는 일정한 진동에너지를 주입재 에 가하여 주입효율을 개선하는 진동주입 공법이 개발된 바 있다.

Yamamoto et al.(2001)은 투수성이 다른 각 암반에서 동적 주입을 실시한 결과 $6 \mathrm{~Hz}$ 주파수로 $5 \mathrm{Lu}$ (루젼)의 암반에서
동적주입 시 정적주입에 비하여 시멘트 주입량이 약 두 배가 량 증가하였고 유사한 균열조건에서 더 많은 양의 약액을 보 다 빠른 시간에 주입할 수 있다는 결론을 얻어낸 바 있다.

Yea et al.(2010)은 가진주입공법의 효과를 검증하기 위 하여 실내에서 제작한 인공절리면에 주입시험을 실시함으 로써 사질토 조성지반에서 $4 \mathrm{kgf}$ 이하의 저압으로 진동주입 시 침투특성이 현저히 개선되며 특히 점성토 지반에서는 다 수의 할열맥을 형성하여 기존공법 대비 개선효과가 상당히 향상되는 것을 확인하였다. 최근 Shin et al.(2012)은 회전하 는 드럼에 부착된 돌기와 접촉볼트가 약액이 통과하는 관 부재를 압박하여 진동을 일으키는 가진발생장치를 이용하 여 실험하였으며, $8 \mathrm{~Hz}$ 의 주파수에서 주입량과 침투범위가 극대화된다는 결과를 얻었다.

한편 국내에는 농업용수 확보를 목적으로 수십 년 전 축 조된 저수지 제당이 전국적으로 다수 분포하고 있다. 노후 된 제당은 근래에 들어 붕괴나 누수의 조짐이 상당수 나타 나고 있어 그에 대한 보수가 이루어지고 있는 실정이다. 본 연구에서는 저수지 제당의 보수용으로 진동주입공법의 효 과를 실제 현장의 사질토 및 점성토 지반에서 검증하기 위 하여 특정 제당구조물에서 일반주입과 진동주입을 동시에 수행한 현장시험을 실시하였다. 두 가지 주입방식의 효과 를 비교하기 위하여 주입량, 표준관입시험치, 현장 투수계 수와 전기비저항치 등을 이용하여 다양한 결과를 얻고 분 석하였다.

\section{2. 진둥주입공법}

진동주입공법은 기존의 주입공법에 진동을 가할 수 있

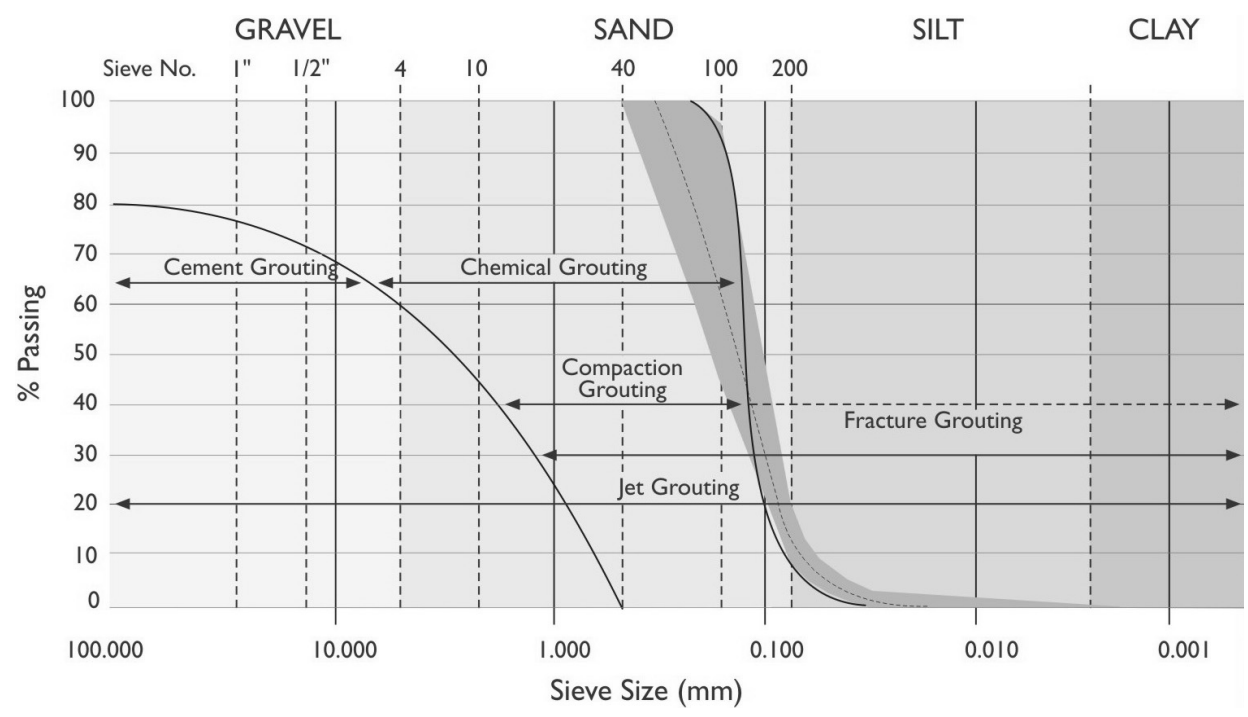

Fig. 1. Grouting methods according to grain size of soil (Hayward Baker Inc, 2013) 
는 펌프를 연결하는 방식으로 이루어지며, 시멘트계 현탁 액 주입재에 정현파(sine wave) 형의 낮은 주파수(7.5 22.5 $\mathrm{Hz}$ )를 누적 가진 시켜 주입하는 공법이다. 진동주입공법을 적용하면 고농도·고점성 시멘트계 그라우트재의 유동성이 증대되어 미세공극이나 미세균열(100 200 $\mu \mathrm{m}$ 이하)이 발 달된 주입 대상체에 대한 침투성이 증대되는 효과가 있다 (Lee, 2009).

주입재에 일정 주파수의 진동에너지를 지속적으로 부가 하면 주입압이 주기적으로 변화하게 되며, 유속의 변화 및 과잉간극수압의 변화를 유발한다. 이와 같은 변화는 유동입 자의 흡착에 영향을 미쳐, 주입 시 입자의 막힘(clogging) 현 상을 감소시킴으로써 그라우트재의 침투성을 증대시킨다. Fig. 2와 Fig. 3은 일반(압력)주입 및 진동주입 $(5 \mathrm{~Hz})$ 시의 시간에 따른 간극수압 변화를 나타낸 그래프이다. 동일한 조건의 세사 모형지반에 물을 일반 및 가진방식으로 주입하 면서 주입구 근처의 간극수압을 수압계로 측정한 값으로서, 일반주입과 비교하여 진동주입 시의 주입압 차이를 확인할

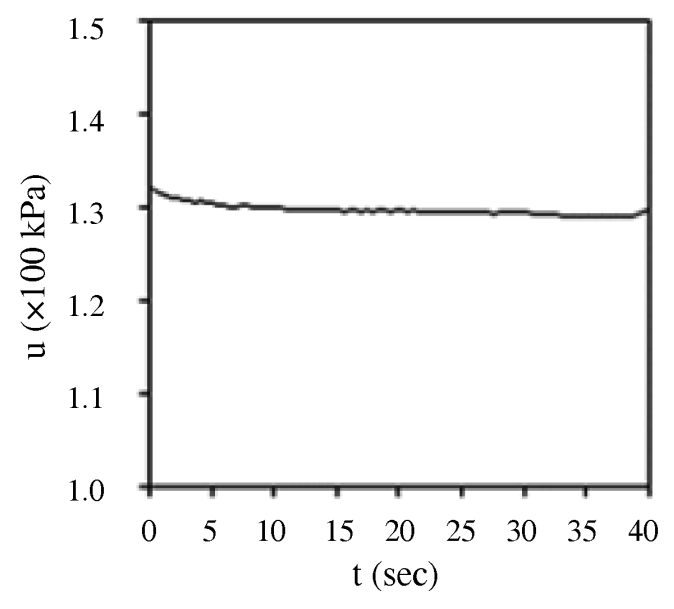

Fig. 2. Pressure variation with time : pressured injection (Samsoo Development Co. et al., 2012)

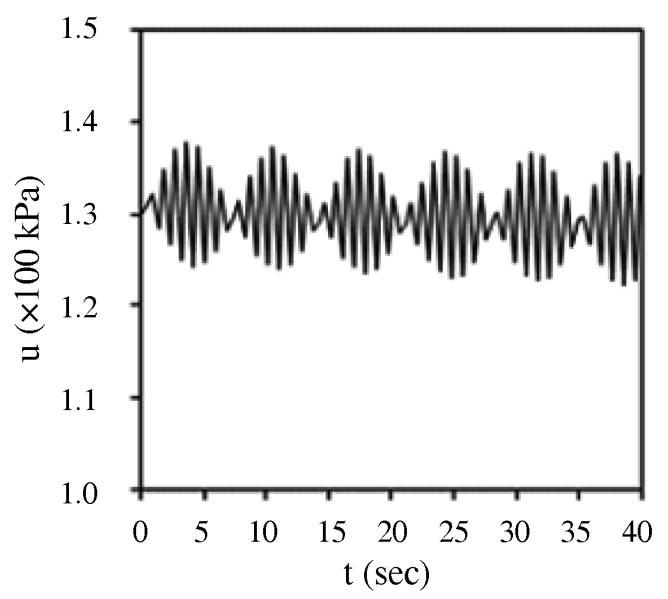

Fig. 3. Pressure variation with time : vibrated injection (Samsoo Development Co. et al., 2012)
수 있다.

Fig. 4에 나타낸 바와 같이 진동발생장치는 크게 진동봉 (vibration rod), 진동판(diaphragm) 및 가진실(vibration room) 로 구성되며 주입재와 접한 진동판을 진동봉이 타격함으로 써 주입재 입자에 진동에너지를 발생시키는 원리이다. 진동 봉은 제어장치에 의해 타격조절이 가능하여 주입재 자체에 특정주파수의 진동에너지를 발생시킬 수 있고 지속적으로 일정하게 주파수를 제어할 수 있도록 되어있다.

\section{3. 지반보강효과 비교를 위한 현장시험}

\section{1 현장시험 개요}

본 연구에서는 동일한 지반조건에서 동일한 주입재료를 가지고 주입방식에 따른 개량효과를 확인하기 위하여 실제 제방의 제체에서 예비시험(pilot test)을 수행하였다. 시험현 장은 농업용 저수지의 제당으로서 제당의 연장은 $740 \mathrm{~m}$, 높이는 $15.9 \mathrm{~m}$ 이며 이 중 일부 구간을 시험대상으로 선정 하였다. Fig. 5는 시험이 이루어진 제당의 위치와 지형을 나타낸다.

일반적으로 농업용 댐의 그라우팅 공사 시 주입압력은 지층이 변위되거나 절리계에 탄성이 미치지 않는 범위에서 최대로 가하여야 한다. 주입압력은 암반에서 $23.0 \mathrm{kPa} / \mathrm{m}$, 토 사층에서는 $10.0 \mathrm{kPa} / \mathrm{m}$ 를 기준으로 하나, 현장에서 주입시 험을 실시하여 파쇄 또는 변위되는 압력을 찾아서 이의 85 $\%$ 를 적정 주입압력으로 채택한다(Korea Rural Community Corporation, 2001). 따라서 본 현장에서 주입시험을 실시한

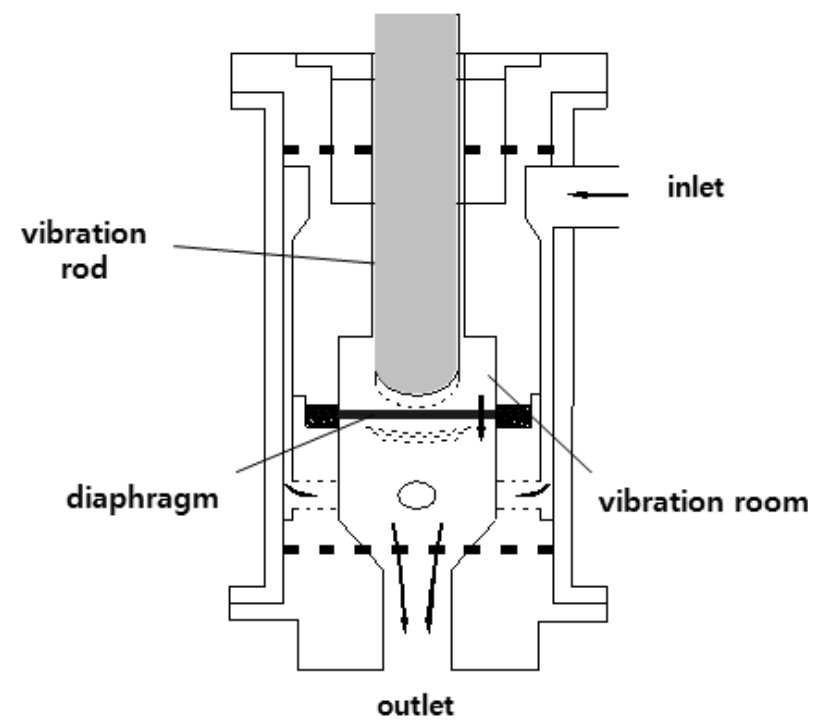

Fig. 4. Schematic of vibration generating system (Samsoo Development Co. et al., 2012) 
결과 $600 \sim 700 \mathrm{kPa}$ 의 압력에서 지반파쇄가 확인되어 상기 주입압력기준과 파쇄압력을 감안하여 압력 주입 시 적정 주 입압을 300 500 kPa로 결정하였다.

시추조사 결과 시험 대상 제당은 상부로부터 성토재 및 코아점토가 최대 $1.5 \mathrm{~m}$ 및 $20.0 \mathrm{~m}$ 심도로 기초지반은 풍화 토 및 풍화암이 최대 $5.0 \mathrm{~m}$ 및 $19.0 \mathrm{~m}$ 로 구성되어 있으며, 그중에서 주입대상 지층은 코아점토 및 풍화토층으로 선정 하였다. Table 1은 시추조사 결과 토층분포를 나타낸다.

\section{2 주입효과 비교}

동일한 지반에서 그라우트재의 주입효과는 약액의 주입 량을 이용하여 쉽게 확인할 수 있다. 따라서 주입방법에 따 른 그라우트재의 주입효과를 비교하기 위하여 주입방식별 로 예비시험을 실시하여 주입량을 비교하였다. Table 2에 나타내었듯이 일반주입과 비교할 때 진동주입 적용 시 시멘 트와 벤토나이트는 약 $14.8 \%$ 만큼 더 주입되었고 그라우트 재의 총 주입량도 같은 비율로 증가한 양상을 보였다. 이는 동일한 지반에서 일반주입공법을 진동주입으로 대체할 경 우 주입공당 주입재의 양이 증가하지만, 지반 내에서 주입

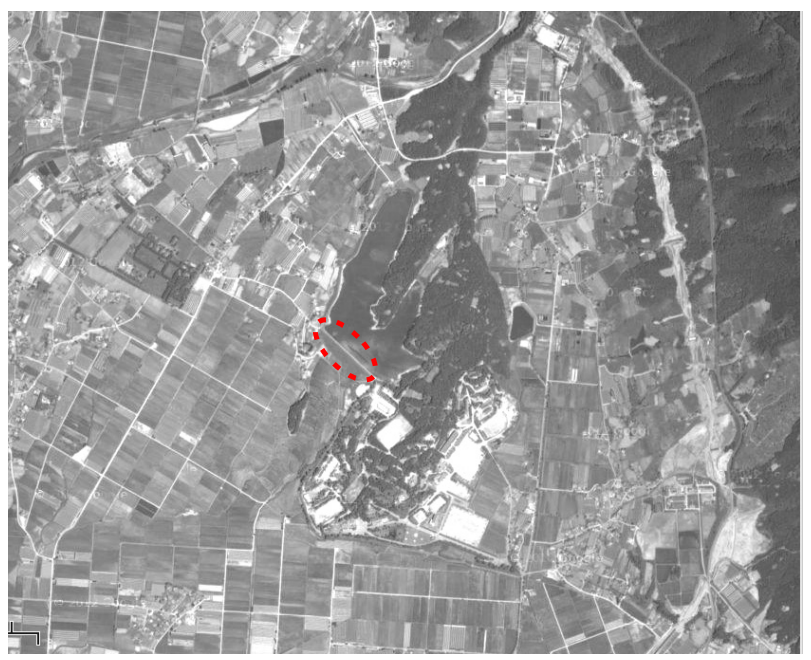

Fig. 5. Location of the embankment for pilot test
반경이 커짐에 따라 주입공의 천공간격이 감소함으로써 공 사비 절감이 가능함을 나타낸다.

\section{3 현장 투수시험}

주입공법에 따라 주입 전·후의 투수성 개선효과를 비교 하기 위하여 현장 투수시험을 실시하였다. 조사 심도인 12.5 $\mathrm{m}$ 까지는 제체 코아점토 및 풍화토로 구성되므로 수위강하 법을 적용하였다. 투수계수의 목표치는 토사층의 경우 $k=\alpha$ $\times 10^{-4} \mathrm{~cm} / \mathrm{sec}$ 의 규정(Korea Rural Community Corporation, 2001)과 타 현장 적용사례를 감안하여 $k=2 \times 10^{-4} \mathrm{~cm} / \mathrm{sec}$ 로 설정하였다.

Fig. 6은 진동주입 및 압력주입 전·후의 심도별 투수계 수 변화를 나타낸다. 진동 및 압력 주입된 구간 가운데 각 각 세 지점에서 수행한 시험결과이다. 주입 전 심도별 투수 계수는 대부분 중간심도 $(5.0 \sim 5.7 \mathrm{~m})$ 까지는 커지나 그 하 부에서는 위치마다 투수계수가 불규칙하게 변화하였다. 이 는 준공 후 오랜 시간이 경과된 제당의 재료상태와 밀도가 매우 불규칙함을 나타낸다. Fig. 6에서 보듯이 주입방식에 관계없이 주입 전에 비하여 주입 후의 투수계수는 현저히 감소하여 개량효과가 있는 것을 확인할 수 있다. 특히 중간 심도 이하에서 불규칙했던 투수계수는 대부분 감소한 것으 로 나타났다. 압력주입 후 투수계수는 전반적으로 주입 전 의 $5.5 \sim 35.1 \%$ 범위로 감소한 반면, 진동주입공법으로 주 입 후 투수계수 범위는 주입 전의 $13.7 \sim 16.9 \%$ 수준까지 감소해 진동주입공법에서 평균적인 투수성 개선효과가 큰 것으로 나타났다.

Fig. 7은 일반주입과 진동주입 후의 투수계수 차이를 나 타낸 것이다. 점선과 실선은 각각 일반주입과 진동주입 시 각 심도에서의 평균 투수계수를 나타낸다. 평균 투수계수의 차이는 최대 $3.11 \times 10^{-5} \mathrm{~cm} / \mathrm{sec}$ 로서 진동주입이 일반주입에 비하여 투수계수가 약 $50 \%$ 까지 감소하여 동일한 지반에서 주입효과가 큰 것을 알 수 있다.

Table 1. Soil layers of the embankment

\begin{tabular}{|c|c|c|c|c|c|c|}
\hline \multirow{2}{*}{ Hole No. } & \multirow{2}{*}{ Station } & \multicolumn{5}{|c|}{ Soil layer (depth, m) } \\
\hline & & Embankment material & Clay (core) & WS & WR & Total \\
\hline BH-1 & No.21 & 1.0 & 7.5 & 5.0 & 17.5 & 31.0 \\
\hline BH-2 & No. $8+7$ & 1.5 & 20.0 & & 19.0 & 40.5 \\
\hline
\end{tabular}

Table 2. Comparison of injected volume according to injection methods

\begin{tabular}{c|c|c|c}
\hline Injection method & Cement (sacks) & Bentonite $(\mathrm{kg})$ & Total injection $\left(\mathrm{m}^{3}\right)$ \\
\hline \hline Vibrated & 4,791 & 8,069 & 134.48 \\
\hline Pressured & 4,172 & 7,027 & 117.11 \\
\hline
\end{tabular}



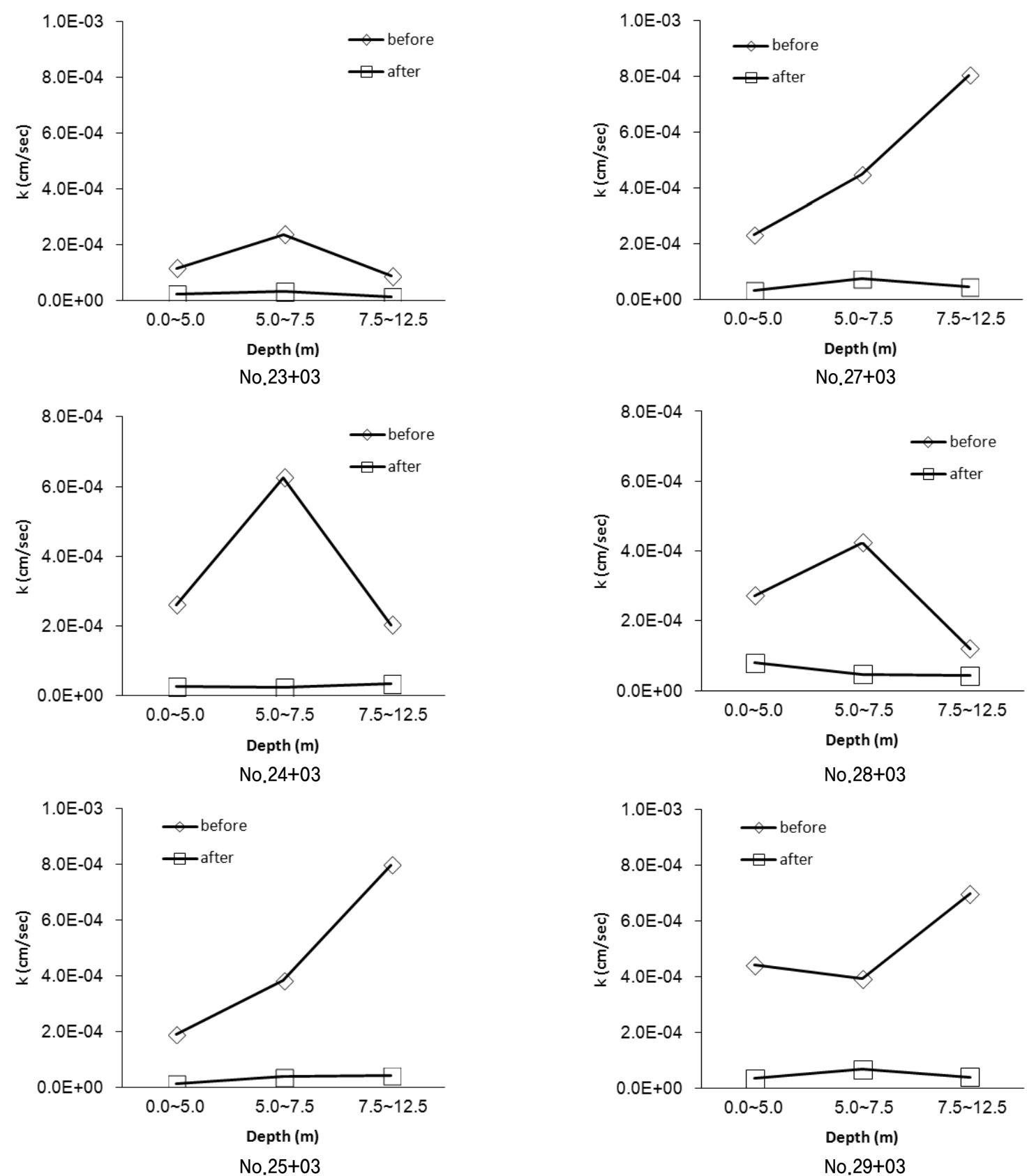

(a) Vibrated

(b) Pressured

Fig. 6. Changes of permeability before and after injection

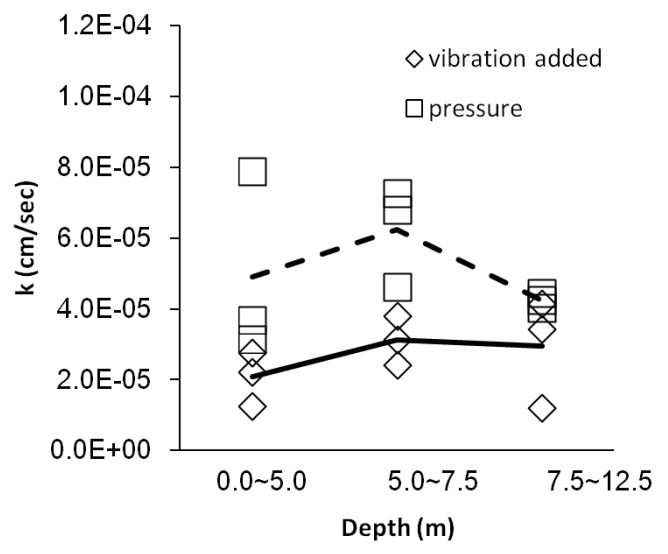

Fig. 7. Permeability according to injection method

\section{4 표준관입시험}

보강 전·후 지반의 강도와 연경도를 조사하기 위하여 각 지반에서 표준관입시험을 실시하였다. 보강 전 제방의 점토 코어와 그 하부 풍화토층의 N치 분포를 Fig. 8에 나타내었 다. 시추조사 결과 지표면에서 $7.5 \mathrm{~m}$ 까지는 점토코어, 그 하 부는 풍화토로 구성되어 있었다. 6 개의 시추공에서 이루어 진 주입 전 원위치시험 결과 점토 코어층의 $\mathrm{N}$ 치는 4 13, 풍화토층의 N치는 8 18 범위에 있다.

Fig. 9는 6개의 시추공에서 압력 및 진동주입공법으로 각 각 보강한 경우의 표준관입시험 결과를 나타낸다. Fig. 9에 


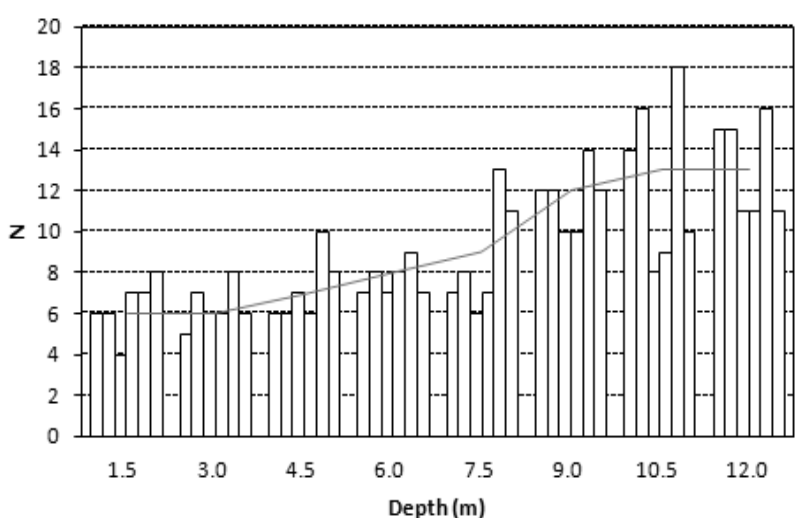

Fig. 8. SPT $\mathrm{N}$ values before injection

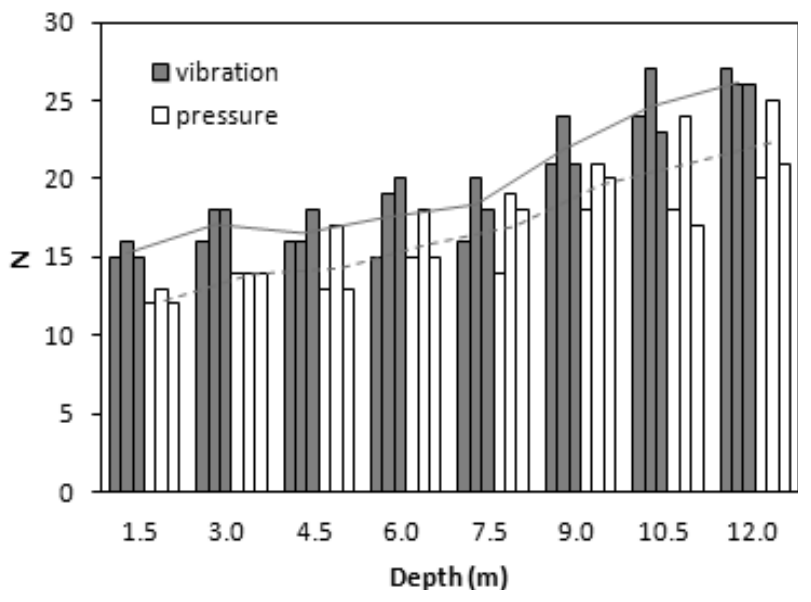

Fig. 9. SPT $\mathrm{N}$ values after injection

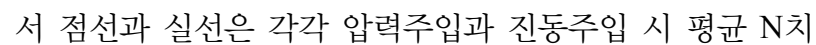
를 나타낸다. 보강 후 점토 코어층의 $\mathrm{N}$ 치 범위는 일반주입 의 경우 $12 \sim 19$, 가진주입의 경우 $15 \sim 20$ 범위로 가진주입 시 평균 $15.8 \%$ 가량 개선효과가 있었다. 또한 풍화토층의 $\mathrm{N}$ 치 범위는 일반주입의 경우 17 25, 진동주입의 경우 21 27 범위로 진동주입 시 평균 $19.0 \%$ 가량 개선되어 진동주 입 시 전반적으로 $17.4 \%$ 가량의 개선효과가 있는 것으로 나 타났으며, 특히 침투형태로의 주입이 용이한 풍화토 지반에 서 개량효과가 상대적으로 컸다.

\section{5 물리탐사}

제체지반 일부의 전반적인 상태를 파악하기 위하여 전기 비저항탐사를 실시하였다. 전기비저항탐사는 지층의 각 매 질별 전기전도도 차이에 따른 상대적인 전기비저항 변화에 따라 지층의 특성을 파악하는 탐사법으로서 댐 등 제체의 누수 상태 확인에 많이 사용되는 탐사법이다.

Fig. 10과 Table 3은 주입 전과 후의 전기비저항 분포를 나타낸다. 주입 전 전기비저항 분포에서 세 구역의 비저항 이상대가 존재함을 확인할 수 있으며(그림의 점선) 이들 구 역에 대하여 진동 및 압력주입 공법을 이용하여 그라우팅을 실시하였다. 공법에 따른 상세한 구간은 Table 3에 나타내 었다. 주입을 실시한 후 주입효과를 확인하기 위하여 다시

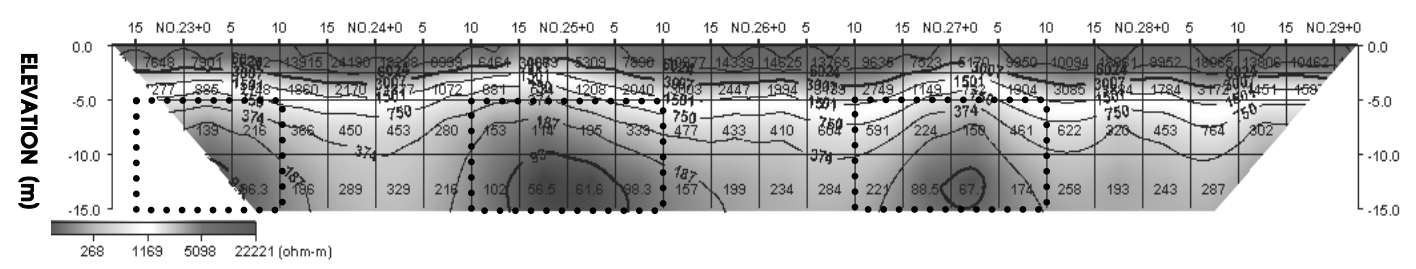

(a) Before injection

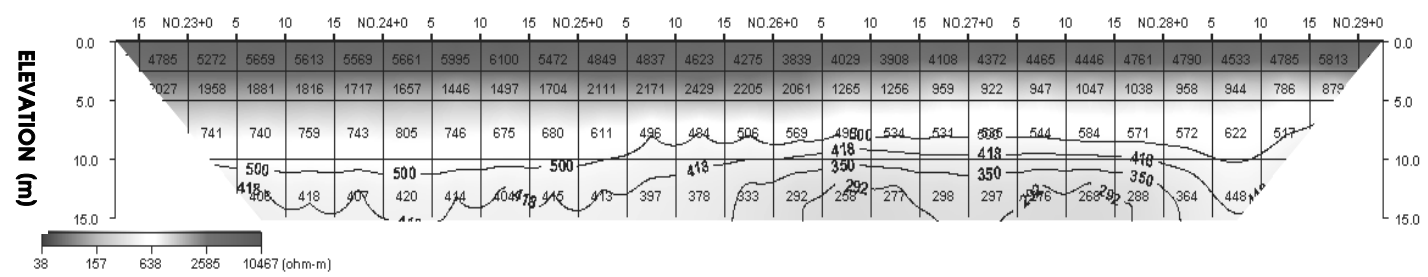

(b) After injection

Fig. 10. Distribution of electrical resistivity

Table 3. Ranges of electrical resistivity by injections

\begin{tabular}{c|c|c|c}
\hline \multirow{2}{*}{ Injection method } & \multirow{2}{*}{ Station } & Ranges of electrical resistivity \\
\cline { 3 - 4 } & & Before injection & After injection \\
\hline \hline Vibrated & No. $22+15 \sim$ No. $23+10$ & 86 & $408 \sim 500$ \\
\hline Vibrated & No. $24+10 \sim$ No. $25+10$ & $56.5 \sim 102$ & $397 \sim 500$ \\
\hline Pressured & No. $26+10 \sim$ No. $27+10$ & $67 \sim 88.5$ & $277 \sim 350$ \\
\hline
\end{tabular}


탐사를 실시한 결과 Fig. 10(b)에 나타났듯이 사전에 확인된 이상대 구간은 주변 지반과 함께 비교적 균일한 비저항치를 보임으로써 지반특성이 개선되었음이 확인되었다. 특히 진 동주입구간에서의 비저항 범위가 일반주입구간에 비하여 상대적으로 높은 값을 보여 균일하고 광범위하게 주입이 이 루어진 것으로 판단된다.

\section{4. 결 론}

본 논문에서는 진동주입공법의 주입효과를 알아보기 위 하여 현장 예비시험을 실시하고 기존의 압력주입공법과 그 결과를 비교·분석하였다. 연구에서 얻은 결론을 요약하면 다음과 같다.

(1) 그라우트재의 주입량을 비교한 결과 일반주입과 비교 할 때 진동주입 적용 시 그라우트재의 총 주입량이 약 $14.8 \%$ 가량 증가한 양상을 보였다.

(2) 주입된 지반에 대하여 현장 투수시험을 실시한 결과 평 균 투수계수는 진동주입이 일반주입에 비하여 약 $50 \%$ 까지 감소하여 동일한 지반에서 균질하고 밀실한 주입 이 이루어진 것으로 나타났다.

(3) 주입 전·후에 지반의 연경도를 확인하기 위하여 표준관 입시험을 실시한 결과 점토 코어층의 $\mathrm{N}$ 치는 일반주입 대비 진동주입 시 평균 $15.8 \%$ 가량 개선효과가 있었고, 풍화토층의 $\mathrm{N}$ 치는 일반주입 대비 진동주입 시 평균 $19.0 \%$ 가량 개선되어 진동주입 시 전반적으로 $17.4 \%$ 가량의 개선효과가 있는 것으로 나타났다. 특히 침투형 태로의 주입이 용이한 풍화토 지반에서 개량효과가 상 대적으로 컸다.

(4) 진동주입구간에서의 전기비저항 범위가 일반주입구간 에 비하여 상대적으로 높은 값을 보여 균일하고 광범위 하게 주입이 이루어진 것으로 판단되었다.
(5) 결론적으로 동일한 지반에서 압력주입을 진동주입으로 대체할 경우 주입공당 주입재의 양은 증가하지만, 주입 재의 확산반경이 커짐에 따라 주입공의 천공간격이 감 소함으로써 공사비 절감이 가능할 것으로 판단된다.

\section{감사의 클}

본 연구는 2013년도 서일대학교 학술연구비 지원에 의해 수행되었으며, 이에 감사드립니다.

\section{References}

1. Bang, G. M., Jeon, H. P. and Jeon, H. T. (2006), Environmental assessment of heavy metal leaching potentials from grouting, Journal of the Korean Society of Mineral \& Energy Resources Engineers, Vol. 43, No. 2, pp. 151 159 (in Korean).

2. Hayward Baker Inc (2013), Grouting related presentation materials, p. 8.

3. Korea Rural Community Corporation (2001), Practical guideline for design \& construction in dam grouting., 463 p. (in Korean).

4. Lee, I. M. (2009), A study on permeability of grout materials applied to vibrating injection method, Korea University Underground Space Lab., pp. 5 7 (in Korean).

5. Samsoo Development Co., Sambu Construction Co. and Dong Myeong Engineering Co. (2012), New excellent technology $2^{\text {nd }}$ examination presentation materials : cement grouting by vibration method, pp. 6 45 (in Korean).

6. Shin, E. C., Shin, H. S. and Ryu, B. H. (2012), Effect of vibration on infiltration grouting using cylindricality device, Korean Geo-environmental Society Conference, pp. 29 34 (in Korean).

7. Yamamoto, T., Hibiya K., Date, K., Shirai, S. and Oba, Y. (2001), Application of dynamic grouting technique to low permeable rock masses, The $56^{\text {th }}$ JSCE Annual Symposium, pp. 642 643 (in Japanese).

8. Yea, G. G, Kim, G. S., Choi, Y. J. and Yang, J. M. (2010), A study on improvement of infiltration grouting using cement grouting by vibration method, Geo-environmental and Slope Stability Conference, pp. 39 47 (in Korean). 